\title{
Dark Friendliness in Austria and Slovenia
}

\author{
BIRGIT BURBÖCK \\ FH Joanneum, Austria \\ birgit.burboeck@fh-joanneum.at \\ ANITA MACEK \\ FH Joanneum, Austria \\ anita.macek@fh-joanneum.at \\ MLADEN VUCKOVIC \\ FH Joanneum, Austria \\ mladen.vuckovic@fh-joanneum.at \\ SONJA LIPAR \\ University of Primorska, Slovenia \\ sonja.lipar@scv.si \\ ŠTEFAN BOJNEC \\ University of Primorska, Slovenia \\ stefan.bojnec@fm-kp.si
}

The paper aims to analyse and compare personal opinion of respondents on corruption perception in Austria and Slovenia with the help of the adoption of the questionnaire of the Global Corruption Barometer of Transparency International. The research results on corruption perception are based on survey sample of 469 respondents in Austria and 410 respondents in Slovenia. The analyses confirmed that the level of corruption differs significantly between Austria and Slovenia, but differences within the country are largely not significant depending on gender. The study proves higher awareness on harms of corruption in Austria, while in the other fields of corruption fighting - corruption as a problem and effectiveness of national governments when fighting against corruption do not differ much between the two countries. The study proves that with entering Slovenian and Austrian business environment the investors will be faced better anticorruption environment in Austria than in Slovenia but corruption risks can appear in each of the country.

Key words: perception of corruption, Global Corruption Barometer of Transparency International, Austria, Slovenia https://doi.org/10.26493/1854-4231.12.375-389

\section{Introduction}

The phenomenon 'corruption' is not new. Before the 1990s, research on corruption was mainly done in the fields of sociology, political science, history, public administration, and criminal law. Since 
then, the economics of corruption became an important field of study, with a wide range of related research (Shleifer and Vishny 1993; Ata and Arvas 2001; Abed and Gupta 2002; Bojnec and Fertő 2017). The descriptions of the term 'corruption' range from very broad terms such as 'misuse of public power' to legal terms describing corruption 'the illegitimate use of public or communal resources for private gain' (Roberts 2015, 82). Melgar, Rossi and Smith (2010) termed government corruption as the misuse of public office with the purpose of making private gain. These descriptions are coherent with the explanation of Transparency International (see https://www.transparency.org/what-is-corruption) which is understood as 'the abuse of entrusted power for private gain.' The most predominant form of corrupt actions occurs when companies bribe public officials (Luo 2004). Considering this fact, international business scholars and economists follow the definition of Transparency International (Judge, McNatt, and Xu 2011).

A body of literature has developed analysing the corruption focusing on developing or emerging countries. For example, Olken (2009) investigated the situation in the road-building industry in Indonesia. Godinez and Liu (2014) studied the relationship between corruption and foreign direct investment (FDI) and tried to explore if corruption deters FDI or not. A different study concentrated on the relationship between corruption and moral schemas in public procurement on the example of Uganda (Ntayi, Ngoboka, and Kakooza 2013). Nevertheless, corruption is not solely a problem in developing or emerging markets, but also in industrialized countries.

To measure the actual corruption rate seems to be difficult, as this particular 'business' is rather secretive and of course illegal. Therefore, involved people tend to avoid talking about this particular issue or participating in experiments dealing with 'corruption' (Armantier and Boly 2011). Therefore, Transparency International (2017) is trying to capture this phenomenon with two indices like the Corruption Perception Index (CPI) and the Global Corruption Barometer (GCB). The main difference between the CPI and the GCP is that the CPI is focusing on the attitudes of business people while the GCP is an opinion survey that reflects the attitude towards corruption of a country's population (Seligson 2006). Several aspects allow criticising the corruption indices. These are too many definitions of corruption as indices and even more subdivisions and interpretations, depending on the country's conduction of the data collection because experts and respondents might have a different idea of the term 'corruption' (Zaman and Faiz-Ur-Rahim 2009). Ogwang and Cho (2014) 
describe as the main weakness of the CPI the different methodology applied in each year and country/territory by Transparency International (2017), which hampers year-to-year and cross-country comparisons in the levels of corruption perceptions. Experts systematically overestimate the frequency of corruption. Therefore, experts do not provide an ideal target group in order to measure the real level of corruption (Razafindraktoto and Roubaud 2010). Furthermore, the CPI measures the general perception of corruption but does not measure specific types of corruption (Ko and Samajdar 2010). The GсB has changed also its methodology over the years. While different research companies conducted the research in each country in 2011, in 2013 and 2016, but only two companies (TNS and Efficience 3) carried out a stratified data collection across all regions. Furthermore, Tns used Computer Assisted Personal Interviews (CAPI) while Efficience 3 used Computer Assisted Telephone Interviews (CATI). Additionally, different questionnaires were used each year, which makes a comparison difficult. Furthermore, the GсB was not measuring corruption in all three time periods in all countries. For example, the GCB was measured in Slovenia in all three periods, while Austria was excluded in 2013 and 2016. However, an exclusion of the GсB does not infer that there is no corruption in Austria.

Research on gender differences is vast but rather limited in the context of corruption. One research stream is for example measuring the effect of women as public officials on corruption. According to Dollar, Fisman, and Gatti (2001) and Swamy et al. (2001), a higher percentage of women as public officials would lead to a decrease of corruption in the subsequent country. Women tend to be less tangled in cases of bribery and are not as tolerate when bribery is at stake. Additionally, if women are more present in the parliament, meaning the share of women is higher, the degree of corruption is not that high (Swamy et al. 2001) because women are more relationshiporiented due to their higher degree of moral behaviour (Rivas 2013). Torgler and Valev (2010) as well as Fišar et al. (2016) show significantly greater aversion to corruption among women because males rather tend to be individualistic or more selfish than females. The resistance of public servants towards corruption is found to relate less to a willingness to report and are less inclined to reciprocate as found by Lambsdorff and Frank (2011). Consequently, women are less willing to harm the common good for an increased personal gain than men are. In particular, this statement holds true for public positions like in the government (Dollar, Fisman, and Gatti 2001). Esarey and Chirillo (2013) argue that this corruption gender gap might ex- 
ist in some countries because women rather comply with political norms as a result of gender discrimination and risk aversion.

We argue that the investigation of the gender difference in corruption should be extended for at least three reasons: First, Rivas (2013) who used a laboratory field experiment for her investigation suggested that further research concerning the relationship of corruption and gender should be conducted. Second, Swamy et al. (2001) also indicated that researchers a very far from reaching a consensus on this issue and further research is required. Third, although research has already been done in the field of corruption in Austria and Slovenia, such as the CPI and GCB, no study has compared how the corruption perception differs among male and females in these two countries.

\section{Theoretical Model}

The theoretical model in figure 1 is based on the Social Role Model, the Evolutionary Theory and the Artifact Model. According to the social role model, the social role assigned to males and females influence the development in the personality, which again influences behaviour. As a result, thinking patterns, feeling and behaviour of men and women are derived from the social roles that are attributed to them (Schmitt et al. 2009). However, Eagly (1987) claims that these roles may also be related to other factors such as childhood socialisation pressures or biological predispositions, but the social roles remain the most influential part.

According to the evolutionary theory, differences in gender are biologically inherent and can be put down to preindustrial age, where men were responsible for hunting and exploring new territories while women took care of the children (Schmitt et al. 2009).

The artefact model can be seen as a combination of the social role model and the evolutionary theory. This model assumes that social roles as well as biology determine differences in gender (Feingold 1994). Therefore, our assumptions are based on three theories in which men are more assertive, aggressive and adventurous than females (Eagly 1987; Feingold 1994; Meyers-Levy and Loken 2015). In other words, we assume that men are more willing to take corrupt actions or are less willing to report cases of corruption than females.

\section{Research Design}

For this research, in addition to the gender question, four questions of the GCB of Transparency International have been adopted and asked: 


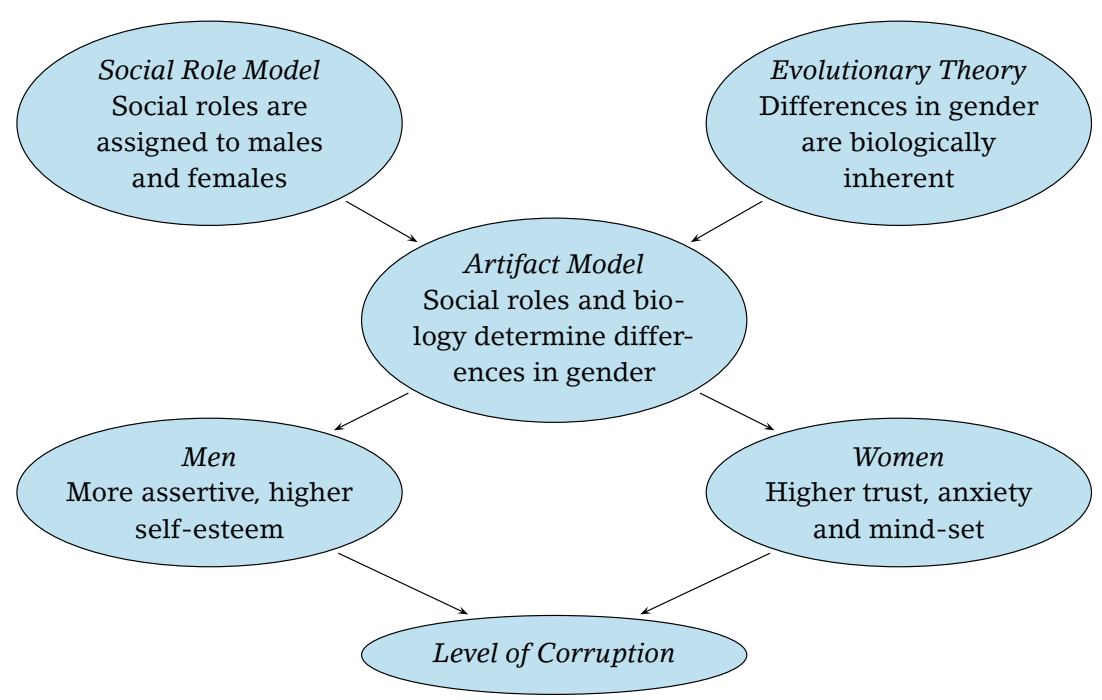

FIGURE 1 Explanatory Model of Level of Corruption (based on Eagly 1987; Feingold 1994; Schmitt et al. 2009)

1. How has according to your opinion changed the level of corruption in Austria/Slovenia?

2. To what extent do you think that corruption in the public sector poses a problem in our country? With the public sector, we refer to employees in organizations/institutions that are owned and/or under the authority of the public sector.

3. In your relations with the public sector, how important is the personal contact/relationship/acquaintance in managing the things that are in the domain of the public sector?

4. How effective do you think is the government in the fight against corruption?

The data collection took place in Austria in the year 2015 and in Slovenia in the year 2016 with a non-stratified sample. The respondents in each country had to be a country citizen with 25 years and older, employed, students with work experience or pensioners. Fulltime students were excluded from the target population. In Austria, the data collection used a mixed method with online-questionnaires as well as paper questionnaires. The reason for additional paper questionnaire was the goal of the researchers to increase the sample size by not excluding those respondents who fulfil the criteria for participating in the survey, but who do not have access to the Internet. The online questionnaire was sent to employees of sev- 
TABLE 1 Respondents by Age Structure

\begin{tabular}{|c|c|c|c|c|}
\hline \multirow[t]{2}{*}{ Age group } & \multicolumn{2}{|c|}{ Austria } & \multicolumn{2}{|c|}{ Slovenia } \\
\hline & $n$ & $\%$ & $n$ & $\%$ \\
\hline $25-34$ & 194 & 41.4 & 71 & $17 \cdot 3$ \\
\hline $35-44$ & 100 & 21.3 & 125 & 30.5 \\
\hline $45-54$ & 95 & 20.2 & 127 & 31.0 \\
\hline $55^{-64}$ & 66 & 14.1 & 76 & 18.5 \\
\hline Over 64 & 14 & 3.0 & 11 & 2.7 \\
\hline Total & 469 & 100.0 & 410 & 100.0 \\
\hline
\end{tabular}

eral companies as well as the customs office. The paper questionnaires were distributed at different gas stations. 518 responses could be collected, among them 378 were collected via the Internet questionnaires and 140 via paper questionnaires. 49 respondents had to be excluded from the analysis, as they have not fulfilled the required criteria for the research. Therefore, only 469 questionnaires could be used for the Austrian analysis.

In Slovenia 1,500 randomly selected e-mails were sent accompanied with an invitation letter to complete the survey via the on-line placed questionnaire. E-mail addresses were found on various websites, both business and private. On the invitation letter responded 789 , which is more than $50 \%$. However, only 417 respondents completed the on-line questionnaire and seven were excluded, because the respondents were below an age of 25 years. Therefore, the sample size of 410 for Slovenia was used, which corresponds to the purpose of our study.

The analysis of data collected for Austria and Slovenia has been conducted using descriptive statistics, independent paired $t$-test, cross-tab Pearson Chi-Square, Likelihood-Ratio test, and Cramer's V-test. The analyses were carried out with Statistical Package for the Social Sciences (spss24). For the analysis we used a total sample size for Austria of $n=469$ and for Slovenia $n=410$. However, it should be noted that for Slovenia on the questions (Q1 and Q2) in the GCB questionnaire are used 408 observations, because one male and one female did not answer on the question, on Q3 406 observations, because four females did not answer on the question, and on Q5 408 observations, because two females did not answer on the question. In both countries, respondents under the age of 25 were excluded. Our research question and hypothesis focus on the difference in the corruption perception between Austria and Slovenia and whether gender can be associated to the corruption perception in the coun- 
TABLE 2 Respondents by Gender

\begin{tabular}{lcccccr}
\hline Gender & Austria & & & \multicolumn{2}{c}{ Slovenia } \\
\cline { 2 - 3 } \cline { 6 - 6 } & $n$ & $\%$ & & $n$ & $\%$ \\
\hline Male & 257 & 54.8 & & 137 & 33.4 \\
Female & 212 & 45.2 & & 273 & 66.6 \\
\hline Total & 469 & 100.0 & 410 & 100.0 \\
\hline
\end{tabular}

try. In this paper, we investigate only four questions (Q1, Q2, Q3 and Q5) in the GCB questionnaire, which has been used in our survey to test the following null (Ho) and alternative (HA) hypothesis:

но There is no significant difference in the corruption perception between Austria and Slovenia.

HA There is a significant difference in the corruption perception between Austria and Slovenia.

\section{Results}

According to the age of respondents, the age distribution for Austria and Slovenia is similar with the most significant groups between 25 and 64 years old (table 1). For Austria, the most represented age groups are 25-34 and 35-44 years old, while for Slovenia age groups 35-44 and 45-54 years old.

Table 2 shows the frequencies in the gender distribution. In Austria $54.8 \%$ of the respondents were male and $45.2 \%$ female. In Slovenia $33.4 \%$ of the respondents were male and $66.6 \%$ were female.

During the most recent years, the level of corruption has changed more in Slovenia than in Austria (table 3). In Slovenia there is also a stronger believe that corruption is a problem in the public sector, while in Austria there are more important personal contacts and/or relationships when dealing with the public sector to get things done. In Slovenia there is also a higher believes in the ineffectiveness of government actions in the fight against corruption than in Austria.

Regarding the question $\mathrm{Q} 1$ on how has according to your opinion changed the level of corruption in the country, it has been found that $43.6 \%$ of respondents in Slovenia believe that the level of corruption in Slovenia remained unchanged in the period of last two years. Other answers go up in the direction of increasing. Finally, 15.4\% of the respondents in Slovenia believe that the level of corruption was little or greatly reduced.

According to gender, $50.7 \%$ of male respondents in Slovenia consider that the level of corruption in Slovenia in the last two years remained the same, just under 19\%, however, that the level of cor- 
Birgit Burböck et al.

TABLE 3 Comparisons of Corruption Perceptions between Austria and Slovenia

\begin{tabular}{llrrrr}
\hline Question & Country & Mean & $\begin{array}{r}\text { Standard } \\
\text { deviation }\end{array}$ & $\begin{array}{r}\text { Std. error of } \\
\text { the mean }\end{array}$ & $\begin{array}{r}\text { Significance } \\
\text { (2-tailed) }\end{array}$ \\
\hline Q1 & Austria & 3.23 & 0.869 & 0.043 & 0.001 \\
& Slovenia & 3.45 & 1.001 & 0.049 & \\
\hline Q2 & Austria & 3.44 & 0.963 & 0.047 & 0.000 \\
& Slovenia & 3.95 & 0.965 & 0.047 & \\
\hline \multirow{2}{*}{ Q3 } & Austria & 3.98 & 0.967 & 0.480 & \multirow{2}{*}{0.000} \\
& Slovenia & 3.57 & 1.140 & 0.056 & \\
\hline \multirow{2}{*}{ 55 } & Austria & 3.43 & 0.813 & 0.040 & 0.000 \\
& Slovenia & 4.00 & 0.789 & 0.039 & \\
\hline
\end{tabular}

Notes Q1 - Over the past two years, how has the level of corruption changed in Austria/Slovenia? ( 1 = decreased a lot, $5=$ increased a lot). Q2 - To what extent to you believe corruption is a problem in the public sector in your country? By public sector we mean all institutions and services that are owned and/or run by the government $(1=$ not a problem at all, $5=$ a very serious problem). Q3 - In your dealings with the public sector, how important are personal contacts and/or relationships to get things done? (1 = not important at all, 5 = very important). Q5 - How effective do you think your government's actions are in the fight against corruption? $(1=$ very effective, $5=$ very ineffective).

TABLE 4 Over the Past Two Years, How Has the Level of Corruption Changed in Austria/Slovenia?

\begin{tabular}{|c|c|c|c|c|c|}
\hline \multirow[t]{2}{*}{ Answer } & & \multicolumn{2}{|c|}{ Austria } & \multicolumn{2}{|c|}{ Slovenia } \\
\hline & & Male & Female & Male & Female \\
\hline \multirow[t]{2}{*}{ Decreased a lot } & c & 1 & 2 & 0 & 3 \\
\hline & $\mathrm{E}$ & 1.6 & 1.4 & 1.0 & 2.0 \\
\hline \multirow[t]{2}{*}{ Decreased a little } & C & 51 & 20 & 25 & 35 \\
\hline & $\mathrm{E}$ & 38.9 & 32.1 & 20.0 & 40.0 \\
\hline \multirow[t]{2}{*}{ Stayed the same } & $\mathrm{C}$ & 125 & 99 & 69 & 109 \\
\hline & $\mathrm{E}$ & 122.7 & 66.0 & $59 \cdot 3$ & 118.7 \\
\hline \multirow[t]{2}{*}{ Increased a little } & $\mathrm{C}$ & 50 & 66 & 17 & 67 \\
\hline & $\mathrm{E}$ & 63.6 & 52.4 & 28.0 & 56.0 \\
\hline \multirow[t]{2}{*}{ Increased a lot } & C & 30 & 25 & 25 & 58 \\
\hline & $\mathrm{E}$ & 30.1 & 24.9 & 27.7 & $55 \cdot 3$ \\
\hline
\end{tabular}

NOTES C-count, $\mathrm{E}-$ expected count.

ruption has increased significantly. On the other hand, $40.1 \%$ of female respondents are of the opinion that the level of corruption in Slovenia in the last two years remained the same, while $24.6 \%$ believe that the level of corruption has increased slightly.

It is believed that corruption stayed at the same level, which is more frequently expressed by male in Austria and female in Slovenia 
table 5 To What Extent Do You Believe Corruption Is a Problem in the Public Sector in Your Country?

\begin{tabular}{lcrrrrr}
\hline Answer & & \multicolumn{2}{c}{ Austria } & & \multicolumn{2}{c}{ Slovenia } \\
\cline { 7 - 7 } & & Male & Female & & Male & Female \\
\hline Not a problem at all & $\mathrm{C}$ & 8 & 3 & & 0 & 5 \\
& $\mathrm{E}$ & 6.0 & 5.0 & & 1.7 & 3.3 \\
\hline A small problem & $\mathrm{C}$ & 36 & 19 & 7 & 24 \\
& $\mathrm{E}$ & 30.1 & 24.9 & 10.3 & 20.7 \\
\hline A moderate problem & $\mathrm{C}$ & 86 & 72 & 28 & 51 \\
& $\mathrm{E}$ & 86.6 & 71.4 & 26.3 & 52.7 \\
\hline A serious problem & $\mathrm{C}$ & 88 & 89 & 44 & 115 \\
& $\mathrm{E}$ & 97.0 & 80.0 & 53.0 & 106.0 \\
\hline A very serious problem & $\mathrm{C}$ & 39 & 29 & & 57 & 77 \\
& $\mathrm{E}$ & 37.3 & 30.7 & 44.7 & 89.3 \\
\hline
\end{tabular}

NOTES C-count, E- expected count.

(table 4). That corruption decreased a lot is least important answer by respondents both in Austria and in Slovenia. On the other hand, more frequent answer in the Austrian sample is that corruption decreased a little and increased a little among male, and particularly increased a little among female. In Slovenia, female evaluated more critically than male particularly for increased a little and increased a lot.

Statistical differences in rankings by gender - male vs. female - on how has the level of corruption changed over the past two years in Austria and in Slovenia are confirmed by Pearson Chi-Square (0.004 for Austria and 0.013 for Slovenia), Likelihood-Ratio test (0.003 for Austria and 0.007 for Slovenia), and Cramer's V-test (0.004 for Austria and 0.013 for Slovenia).

That corruption is a problem in the public sector is recognized in both Austria and Slovenia (table 5). As the public sector is defined with all institutions and services which are owned and/or run by the government.

Both in Austria and Slovenia only a small percentage of respondents believe that corruption in the public sector is not a problem. The most common single answer in Austria and in Slovenia was that corruption in the public sector is a serious problem. This is confirmed also by gender, particularly for male in Austria and female in Slovenia. A moderate problem of corruption in the public sector is recorded as the second most frequent answer in Austria, while a very serious problem in Slovenia. For example, almost $42 \%$ of male respondents in Slovenia answered that corruption in the public sec- 
TABLe 6 In Your Dealings with the Public Sector, How Important are Personal Contacts to Get Things Done?

\begin{tabular}{lcrrrrrr}
\hline Answer & & \multicolumn{2}{c}{ Austria } & & \multicolumn{2}{c}{ Slovenia } \\
& & Male & Female & & Male & Female \\
\hline Not important at all & $\mathrm{C}$ & 3 & 3 & & 5 & 13 \\
& $\mathrm{E}$ & 3.3 & 2.7 & & 6.1 & 11.9 \\
\hline Of little importance & $\mathrm{C}$ & 26 & 14 & & 24 & 36 \\
& $\mathrm{E}$ & 21.9 & 18.1 & & 20.2 & 39.8 \\
\hline Moderately important & $\mathrm{C}$ & 35 & 29 & & 38 & 65 \\
& $\mathrm{E}$ & 35.1 & 28.9 & 34.8 & 68.2 \\
\hline Important & $\mathrm{C}$ & 108 & 92 & & 40 & 83 \\
& $\mathrm{E}$ & 109.6 & 90.4 & & 41.5 & 81.5 \\
\hline Very important & $\mathrm{C}$ & 85 & 74 & & 30 & 72 \\
& $\mathrm{E}$ & 87.1 & 71.9 & & 34.4 & 67.6 \\
\hline
\end{tabular}

NOTES C-count, E- expected count.

tor represents a very serious problem, while no one thinks it is not a problem. On the other hand, $42.3 \%$ of female respondents in Slovenia believe that corruption in the public sector is a serious problem and only $1.8 \%$ that it is not a problem. Statistical differences in rankings by gender on the extent of corruption in the public sector in Austria and Slovenia are not confirmed for Austria, but they are confirmed for Slovenia: Pearson Chi-Square (o.201 for Austria and 0.02 for Slovenia), Likelihood-Ratio test (0.192 for Austria and 0.01 for Slovenia), and Cramer's V-test ( 0.113 for Austria and 0.169 for Slovenia). This means that there is no association between gender and attitude towards corruption in the public sector in Austria, while it is in Slovenia.

In relations with the public sector are important the personal contact/relationship/acquaintance in managing the things that are in the domain of the public sector as this is the most frequent single answer in Austria as well as in Slovenia (table 6).

Only small percentage of respondents believes that the friendships they have no influence on managing the things that are within the domain of the public sector. In Austria, on the second place is ranked that the acquaintances were very important, while in Slovenia almost equally important are moderately important and very important. Statistical differences in rankings by gender on how important are personal contacts to get things done in dealing with the public sector in Austria and Slovenia are not confirmed by Pearson ChiSquare (0.754 for Austria and 0.604 for Slovenia), Likelihood-Ratio test (0.747 for Austria and 0.604 for Slovenia), and Cramer's V-test 
TABLe 7 How Effective You Think Your Government Actions Are in the Fight against Corruption?

\begin{tabular}{|c|c|c|c|c|c|}
\hline \multirow[t]{2}{*}{ Answer } & & \multicolumn{2}{|c|}{ Austria } & \multicolumn{2}{|c|}{ Slovenia } \\
\hline & & Male & $\overline{\text { Female }}$ & Male & Female \\
\hline \multirow[t]{2}{*}{ Very effective } & c & 1 & 2 & o & 2 \\
\hline & E & 1.6 & 1.4 & 0.7 & 1.3 \\
\hline \multirow[t]{2}{*}{ Effective } & c & 32 & 23 & 4 & 5 \\
\hline & $\mathrm{E}$ & 30.1 & 24.9 & 3.0 & 6.0 \\
\hline \multirow{2}{*}{$\begin{array}{l}\text { Neither effective } \\
\text { nor ineffective }\end{array}$} & C & 97 & 89 & 23 & 64 \\
\hline & E & 101.9 & 84.1 & 29.2 & 57.8 \\
\hline \multirow[t]{2}{*}{ Ineffective } & c & 101 & 85 & 68 & 131 \\
\hline & $\mathrm{E}$ & 101.9 & 84.1 & 66.8 & 132.2 \\
\hline \multirow[t]{2}{*}{ Very ineffective } & c & 26 & 13 & 42 & 69 \\
\hline & $\mathrm{E}$ & 26.4 & 17.6 & $37 \cdot 3$ & 73.7 \\
\hline
\end{tabular}

NOTES C-count, E- expected count.

(0.064 for Austria and 0.082 for Slovenia). This means that there is no association between gender and attitude towards corruption in terms of dealings with the public sector using personal contacts to get things done.

Regarding how effective is the government in the fight against corruption, in Austria, most of male and female respondents think that government actions in the fight against corruption are neither effective nor ineffective or even they are ineffective (table 7). Ineffective and very ineffective is even more important for Slovenia. Almost half of the respondents $(48.8 \%)$ in Slovenia were of the opinion that the government in the fight against corruption is ineffective. According to gender in Slovenia, male in $49.6 \%$ believe that the government is ineffective in the fight against corruption, while female in $48.3 \%$. This was also their most frequent single response. Barely $2.7 \%$ of respondents in Slovenia believe that the government is very or only effective in the fight against corruption. Effective is more frequent answer in Austria than in Slovenia, while very effective is not important neither in Austria nor in Slovenia. Statistical differences in rankings by gender on how effective is the government in the fight against corruption, neither in Austria nor in Slovenia are not confirmed by Pearson Chi-Square (0.467 for Austria and 0.604 for Slovenia), Likelihood-Ratio test ( 0.458 for Austria and 0.604 for Slovenia), and Cramer's V-test (0.087 for Austria and 0.082 for Slovenia). This means that there is no association between gender and attitude towards effective government actions towards corruption neither in Austria nor in Slovenia. 


\section{Discussion}

The paper is based on the analysis and comparisons of the results from own surveys data with used a questionnaire for GсB in Austria and Slovenia, the two neighbouring countries, both members of the European Union (EU). A sample population represented residents in the country aged at least 25 years old, employed students with work experience and pensioners. The sample was non-stratified, assigned to the randomly selected respondents. Our research question and hypothesis have focused on the difference in the corruption perception of respondents between Austria and Slovenia and separately in relation to gender associated the corruption perception. Our research has answered on the question of corruption perception in the Austrian and Slovenian societies. By using the descriptive statistics, we show a sample characteristics of the survey data and/or demographic characteristics of the respondents in connection with the chosen first four questions in the Gсв questionnaire.

The higher level of economic development measured by gross domestic product per capita, earlier membership of Austria in the EU, cultural and some other differences can be reasons for more clean of corruption behaviour in Austria than in Slovenia, which is also consistent with the CPI by Transparency International (2017). For example, in 2016, among 176 countries, Austria with cPI score of 75 is ranked at the 17th place on the top among the most clean of corruption countries, while Slovenia with CPI score of 61 on the 31th place, considering that CPI is scaled between o (highly corrupt) and 100 (very clean).

\section{Conclusion}

The main novelty and contribution of this paper is in comparison GCB measures in Austria and Slovenia. The empirical results have confirmed significant difference in the perception of corruption between Austria and Slovenia. The change in the level of corruption and corruption in the public sector is found higher in Slovenia than in Austria. Personal contacts are more important in Austria than in Slovenia, while the ineffectiveness of government action to fight corruption is perceived higher in Slovenia than in Austria. Gender cannot explain the different perception of corruption in Austria and Slovenia.

Although this paper covers more aspects of corruption on a gender perspective, the study also has some notable limitations and thus possible direction for research in future. Firstly, the research does 
not take any other demographic variables, such as age and occupation, into account. These variables could be considered in future research when analysing different aspects of corruption. Secondly, it would have also been interesting to find out whether corruption is influenced by other characteristics in both countries, such as its national competitiveness. For example, Ulman (2014) found out that the level of national competitiveness, including factors as the standard of living, the rate of employment, significantly influences the perception of corruption. Thirdly, this research focuses only on Austria and Slovenia and does not compare results with other countries. Therefore, an idea to extend this research would be a cross-country comparison. However, when considering a cross-national study, the culture and history have to be considered, as Bhargava (2005) found out that corruption is heavily influenced by these factors. Finally, among limitations of this study is relatively small sample size and the sample has not been stratified.

In addition, the questionnaire was based on four Gсв index questions, while the data collected for the remaining questions in the GCB questionnaire have not been analysed in this paper. Therefore, among issues for further research are improvements in sampling procedure towards stratified sample, bigger sample size, analysis of additional answers of the GсB index questions and comparisons with CPI index questions.

\section{References}

Abed, G. T., and S. Gupta. 2002. Governance, Corruption and Economic Performance. Washington, DC: International Monetary Fund.

Armantier, O., and A. Boly. 2011. 'A Controlled Field Experiment on Corruption.' European Economic Review 55 (8): 1071-82.

Ata, A. Y., and M. A. Arvas. 2011. 'Determinants of Economic Corruption: A Cross Country Analysis.' International Journal of Business and Social Science 2 (13): 161-9.

Bhargava, V. 2005. 'The Cancer of Corruption.' http://siteresources .worldbank.org/EXTABOUTUS/Resources/Corruption.pdf

Bojnec, Š., and I. Fertő. 2017. 'Effects of Globalization and Corruption on the Outward FDI in OECD Countries.' Journal of Economics 65 (3): 201-19.

Dollar, F., R. Fisman, and R. Gatti. 2001. 'Are Women Really the "Fairer Sex?" Corruption and Women in Government.' Journal of Economic Behavior and Organization 46:423-9.

Eagly, A. (1987). Sex Differences in Social Behavior: A Social-Role Interpretation. Hillsdale, NJ: Lawrence Erlbaum.

Esarey, J., and G. Chirillo. 2013. "“Fairer Sex” or Purity Myth? Corrup- 
tion, Gender, and Institutional Context.' Politics and Gender 9 (4): 361-89.

Feingold, A. 1994. 'Gender Differences in Personality: A Meta-Analysis.' Psychological Bulletin 116 (3): 429-56.

Fišar, M., M. Kubák, J. Špalek, and J. Tremewan. 2016. 'Gender Differences in Beliefs and Actions in a Framed Corruption Experiment.' Journal of Behavioral and Experimental Economics 63:69-82.

Godinez, J., and R. Liu. 2014. 'Corruption Distance and FDI Flows into Latin America.' International Business Review 24 (1): 33-42.

Judge, W. Q., D. B. McNatt, and W. Xu. 2011. 'The Antecedents and Effects of National Corruption: A Meta-Analysis.' Journal of World Business 46 (1): 93-103.

Ko, K., and A. Samajdar, A. 2010. 'Evaluation of International Corruption Indexes: Should We Believe Them Or Not?' Social Science Journal 47 (3): 508-40.

Lambsdorff, J. G., and B. Frank. 2010. 'Corrupt Reciprocity - Experimental Evidence on a Men's Game.' International Review of Law and Economics 31:116-25.

Luo, Y. 2004. 'An Organizational Perspective of Corruption.' Management and Organization Review 1 (1): 119-54.

Melgar, N., M. Roosi, and T. Smith. 2010. 'The Perception of Corruption.' International Journal of Public Opinion Research 22 (1): 120-31.

Meyers-Levy, J., and B. Loken. 2015. 'Revisiting Gender Differences: What We Know and What Lies ahead.' Journal of Consumer Psychology 25 (1): 129-49.

Ntayi, J., P. Ngoboka, and C. Kakooza. 2013. 'Moral Schemes and Corruption in Ugandan Public Procurement.' Journal of Business Ethics 112 (3): 417-36.

Ogwang, T., and D. Cho. 2014. 'A Conceptual Framework for Construction a Corruption Diffusion Index.' Journal of Business Ethics 125 (1): 1-9.

Olken, B. 2009. 'Corruption Perception vs. Corruption Reality.' Journal of Public Economics 93:950-64.

Razafindrakoto, M., and F. Roubaud. 2010. 'Are International Databases on Corruption Reliable? A Comparison of Expert Opinion Surveys and Household Surveys in Sub-Saharan Africa.' World Development 38 (8): 1057-69.

Rivas, M. F. 2013. 'An Experiment on Corruption and Gender.' Bulletin of Economic Research 65 (1): 10-42.

Roberts, J. 2015. 'The "Subject" of Corruption.' Critical Perspectives on Accounting 28:82-8.

Schmitt, D., A. Realo, M. Voracek, and J. Allik. 2009. 'Why Can't a Man be More Like a Woman? Sex Differences in Big Five Personality Traits across 55 Cultures.' Journal of Personality and Social Psychology 96 (1): 168-82. 
Seligson, M. 2006. 'The Measurement and Impact of Corruption Victimization: Survey Evidence from Latin America.' World Development $34(2): 381-404$.

Shleifer, A., and R. Vishny. 1993. 'Corruption.' Quarterly Journal of Economics 108 (3): 599-617.

Swamy, A., S. Knack, Y. Lee, and O. Azfar. 2001. 'Gender and Corruption.' Journal of Development Economics 64:25-55.

Torgler, B., and N. Valev. 2010. 'Gender and Public Attitudes toward Corruption and Tax Evasion.' Western Economic Association International 28 (4): 554-68.

Transparency International. 2017. 'Corruption Perception Index 2016.' https://www.transparency.org/news/feature/corruption _perceptions_index_2016\#table

Ulman, S.-R. (2014). 'The impact of National Competitiveness on the Perception of Corruption.' Procedia Economics and Finance 15:10029.

Zaman, A., and Faiz-Ur-Rahim. 2009. 'Corruption: Measuring the Unmeasurable.' Humanomics 25 (2): 117-26. 